\title{
MASTER
}

\section{Flowability of Bulk Solids Used in Shale Fracturing Grouts as Determined by the Jenike and Johanson Method}

\author{
Earl W. McDaniel \\ H. O. Weeren
}

OAK RIDGE NATIONAL LABORATORY OPERATED BY UNION CARBIDE CORPORATION - FOR THE DEPARTMENT OF ENERGY 


\section{DISCLAIMER}

This report was prepared as an account of work sponsored by an agency of the United States Government. Neither the United States Government nor any agency Thereof, nor any of their employees, makes any warranty, express or implied, or assumes any legal liability or responsibility for the accuracy, completeness, or usefulness of any information, apparatus, product, or process disclosed, or represents that its use would not infringe privately owned rights. Reference herein to any specific commercial product, process, or service by trade name, trademark, manufacturer, or otherwise does not necessarily constitute or imply its endorsement, recommendation, or favoring by the United States Government or any agency thereof. The views and opinions of authors expressed herein do not necessarily state or reflect those of the United States Government or any agency thereof. 


\section{DISCLAIMER}

Portions of this document may be illegible in electronic image products. Images are produced from the best available original document. 
Printed in the United States of America. Available from National Technical Information Service

U.S. Department of Commerce

5285 Port Royal Road, Springfield, Virginia 22161

Price: Printed Copy $\$ 4.50$; Microfiche $\$ 3.00$

This report was prepared as an account of work sponsored by an agency of the United States Government. Neither the United States Government nor any agency thereof, nor any of their employees, contractors, subcontractors, or their employees, makes any warranty, express or implied, nor assumes any legal liability or responsibility for any third party's use or the results of such use of any information, apparatus, product or process disclosed in this report, nor represents that its use by such third party would not infringe privately owned rights. 
Contract No. 7405-eng-26

CHEMICAL TECHNOLOGY DIVISION

NUCLEAR FUEL AND WASTE PROGRAMS

Hydrofracture Mix Development Studies

(Activity No. JM $0501030 ; 189$ No. ON $66 \quad 09$ A)

FLOWABILITY OF BULK SOLIDS USED IN SHALE FRACTURING

GROUTS AS DETERMINED BY THE JENIKE AND JOHANSON METHOD

Ear1 W. McDante1

H. 0 . Weeren

Date Published - September 1979

OAK RIDGE NATIONAL LABORATORY

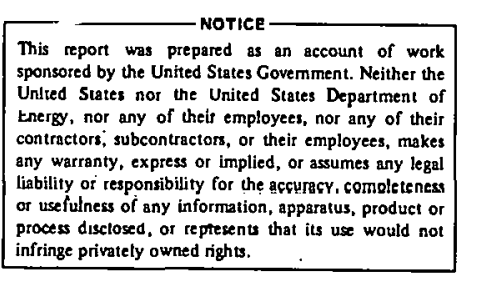

Oak Ridge, Tennessee 37830

operated by

UNION CARBIDE CORPORATION

for the

DEPARTMENT OF ENERGY 


\section{THIS PAGE}

WAS INTENTIONALLY

LEFT BLANK 
CONTENTS

$\underline{\text { Page }}$

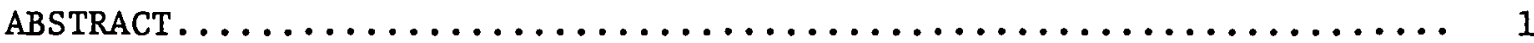

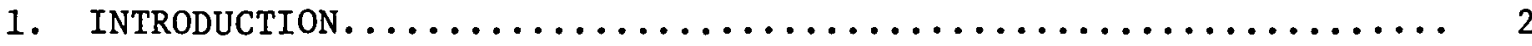

1.1 Existing Solids Handling System.................. 2

1.2 New Solids Handling System..................... 4

1.3 Flow Characteristics of Solids................... 6

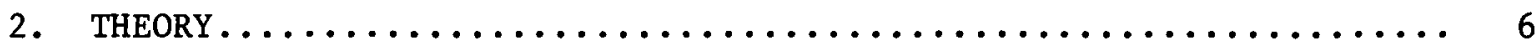

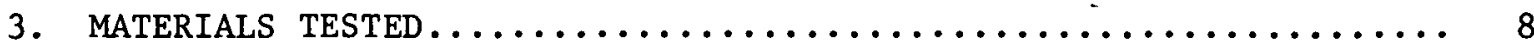

3.1 Attapulgite-150.......................... 8

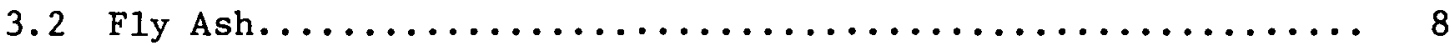

3.3 Pottery Clay................................ 8

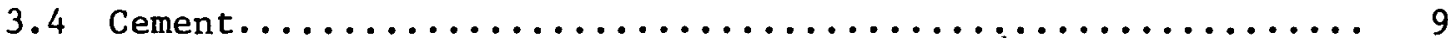

3.5 Dry Solids Blend.......................... 9

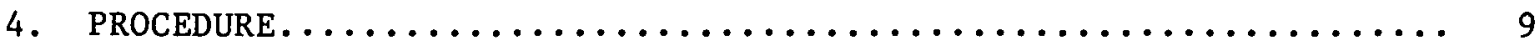

4.1 Apparatus and Test Procedure.................... 9

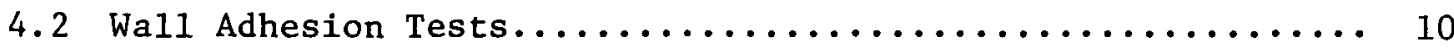

4.3 Plotting Test Results........................ 10

5. DATA UTILIZATION............................. 12

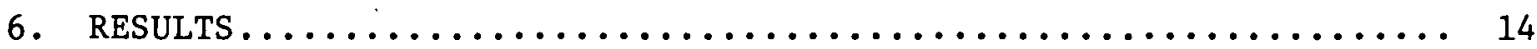

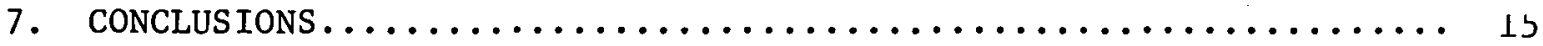

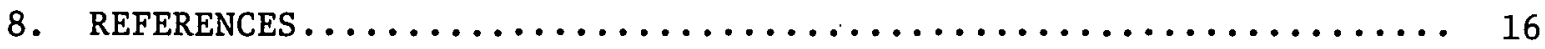


FLOWABILITY OF BULK SOLIDS USED IN SHALE FRACTURING GROUTS AS DETERMINED BY THE JENIKE AND JOHANSON METHOD

Earl W. McDaniel

H. 0 . Weeren

ABSTRACT

Smooth operation of the shale fracturing facility at Oak Ridge National Laboratory requires that an even, uninterrupted flow of dry solids be delivered to a mixer at a rate of approximately $1200 \mathrm{lb} / \mathrm{min}$. Some operational difficulties have been experienced with the dry solids system at the existing facility. Occasionally the solids flow from a bin was difficult to initiate or was irregular, particularly when the storage bin was nearly empty. A new shale fracturing facility is now being designed with a solids handling system that will eliminate the current problems. This report describes the tests made to obtain the necessary information about bulk-flow properties of the dry solids that are required for the facility modifications.

The flow properties of fly ash, attapulgite, pottery clay, and a blended solids $\mathrm{mlx}$ were determined in a Jenike and Johanson Flowfactor Tester. Tests with this unit involve the consolidation of a solid at a given pressure and the measurement of the force required to create a shear plane. The procedure is repeated several times at different consolidating pressures to determine a locus of points that can be displayed graphically.

The results indicate that a bottom-hopper opening of about $4 \mathrm{ft}$ will be required on the new, bulk storage bins if mass flow is to be achieved. It was also found that the existing bins are quite unsuitable for either their present function (storage of dry mix) or their proposed function (storage of mix components). Since these bins have served moderately well for 14 years, the effect of aeration (not allowed for in these tests) is obviously major; these tests indicate only an upper limit to the size of the hopper opening that will be required.

Pottery clay and attapulgite were found to have flow characteristics considerably inferior to blended solids. It is known, however, that attapulgite clay will flow from the existing bins, and modification of the bin bottoms to enlarge the openings does not appear to be justified. 


\section{INTRODUCTION}

The shale fracturing process for the permanent disposal of locally generated intermediate-level waste solutions is currently in use at Oak Ridge National Laboratory (ORNL). In this process, the waste solution is mixed with a solids blend of cement and other additives; the resulting grout is injected into an impermeable shale formation at a depth of 700 to $1000 \mathrm{ft}^{1}$ The existing facility was built in 1963 and has since been used to inject over 2.5 million gal of waste grout. ${ }^{2}$ One of the princlpal improvements that will be incorporated into the design of a new waste disposal facility will be modifications to the dry-solids handling equipment so that the flow of dry solids will be smooth and uninterrupted.

\subsection{Existing Solids Handling System}

The dry-solids handling system at the existing shale fracturing facility consists of a solids blending system and a dry-solids bulk storage system. A flow diagram of the two systems is shown in Fig. 1.

The ingredients of the dry solids blend (Portland cement, fly ash, attapulg1te drilling clay, pottery clay, and a small amount of retarder) are charged separately to a weigh tank. The amount of each ingredient charged is in the proper proportion to make up a hatch of about 40,000 $1 \mathrm{~b}$. The weigh tank is pressurized and the batch of solids is blown into the first of the blending tanks. This tank is then pressurized and the batch of solids is blown Into the second blending tank. Finally, the batch of solids is blown from the second blending tank into one of the four bulk storage bins. Fifteen batches of dry solids are blended in this manner for each injection; this operation requires approximately five working days. 'lhe operating experience with this system has been quite good, and the system will be used in the same manner in the new facility.

The dry-solids bulk storage system consists of four storage bins, four air slides leading to a mixer hopper, and a small mixer hopper. Each of the storage bins is $12 \mathrm{ft}$ in diameter. The height of the cylindrical part of the bin is $20 \mathrm{ft}$ and the height of the conical bottom section is $8-1 / 2 \mathrm{ft}$ (the included cone angle is $70^{\circ}$ ). An assembly of 
ORNL DWG $79-872$

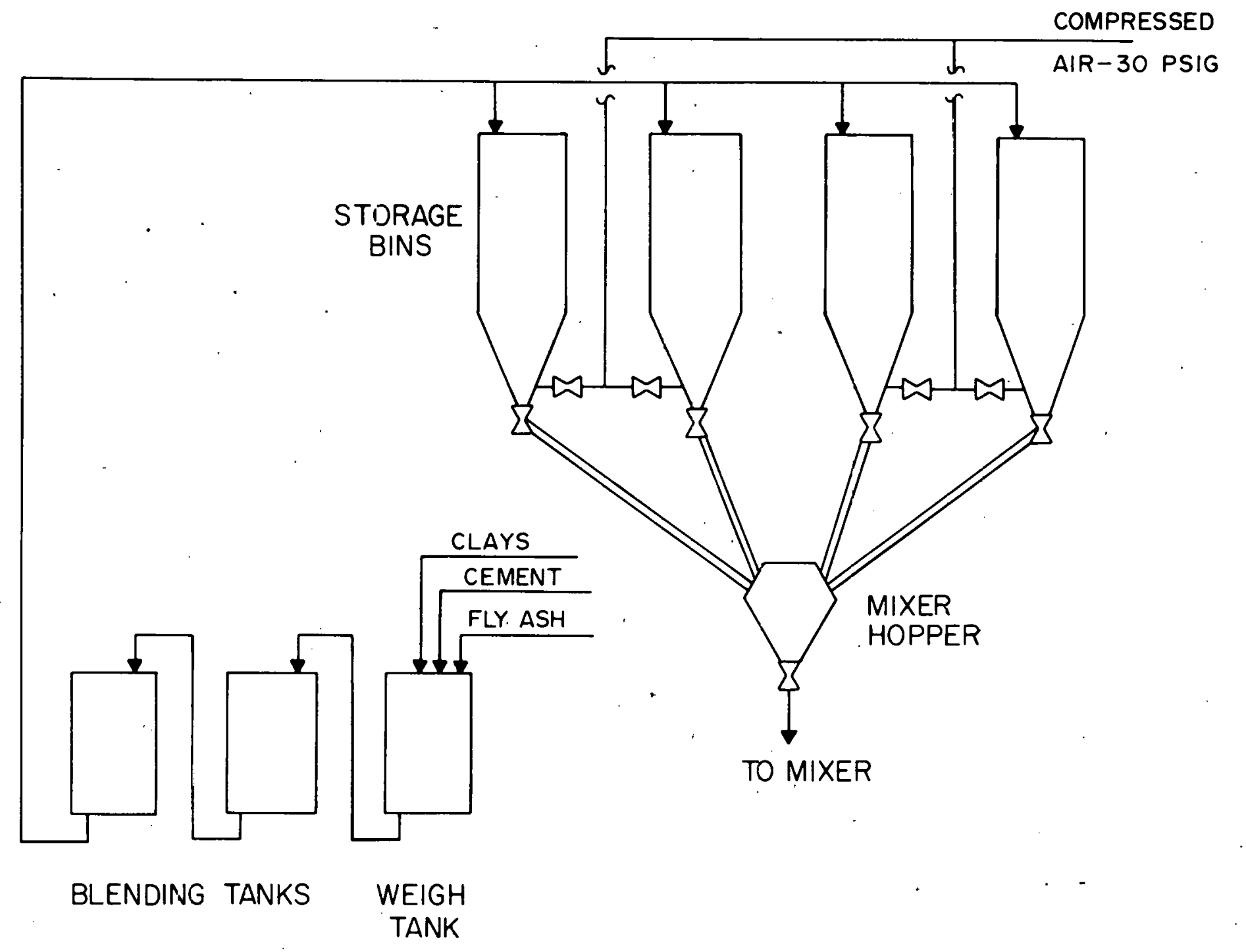

Fig. 1. Existing solids blending and dry-solids bulk storage system. 
aeration nozzles is installed in the center of each bin near the bottom of the cone. From 100 to $150 \mathrm{cfm}$ of air at a pressure of $30 \mathrm{psig}$ is supplied to the aeration nozzles during each injection. At the bottom of each bin is an 8-in. butterfly discharge valve. During an injection, the dry solids are discharged through the bottom valve into an air slide from which they flow to the mixing hopper. An air slide is a covered trough with a porous bottom through which low-pressure air can diffuse to fluidize the solids. The mixing hopper is a small surge tank. Normally, a solids storage bin is aerated for about $30 \mathrm{~min}$ prior to the withdrawal of solids. Solids are generally withdrawn from only one hin at a time.

Some operational difficulties have been experienced at the existing facility with the dry solids system, such as:

1. problems in initiating the flow of solids from a bin;

2. irregular solids flow from a bin, particularly when a bin is almost empty. This irregular solids flow has caused severe problems with controlling the solids-to-liquid proportioning.

\subsection{New Solids Handling System}

In the new solids handling system, the bulk storage hins at the existing facility will be moved to the new site and used for the storage of individual mix components of attapulgite, pottery clay, and fly ash. The existing blending system will be used essentially as is. Two new bulk storage tanks will be built, each with a capac1ty of 500,000 lb of blended solids. Solids will be withdrawn from the bottom of these bins and pneumatically transferred to a head tank located above the mixer. The solids will flow by gravity out of the head tank to the mixer. A flow diagram of the new solids handling system is shown in Fig. 2 .

A smooth flow of blended solids out of the head tank will be vital to the proper operation of the new solids system. Although smooth flow from the blended-solids bulk storage bins would be desirable, it is not quite as necessary. Adequate flow of individual mix components from the component storage bins will be desirable, but smooth flow is not essential in this case. The smooth flow of solids out of storage bins can be 
ORNL DWG 79-871

STORAGE BINS
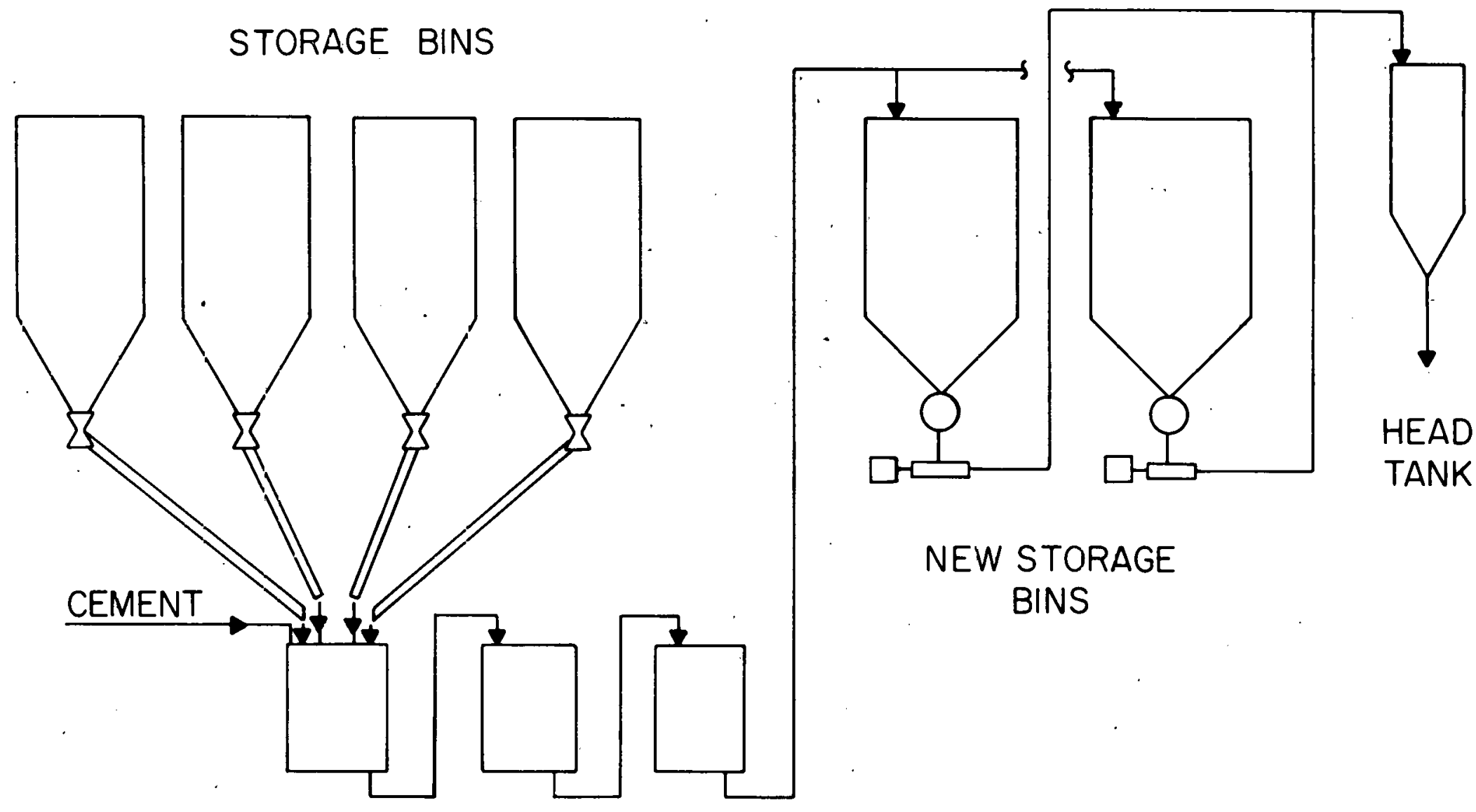

HEAD

TANK

ง

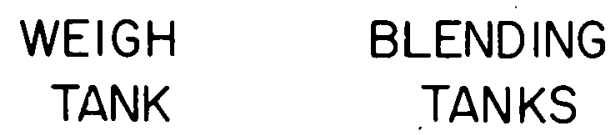

Fig. 2. New solids handling system. 
determined by design features such as the size of the bottom opening, cone wall angle, materials of bin construction, method of aeration, and number and location of vibrators. Before these features can be evaluated, the flow characteristics of the various dry solids must be determined.

\subsection{Flow Characteristics of Solids}

The theory of flow of bulk solids and the design of storage bins and channels for flow have been the subjects of extensive studies by Jenike. ${ }^{3}$ These studies have led to the concept of the different flow patterns that may occur within a solids storage bin: funnel flow (in which the solids drawn through an outlet form a channel within the stored solids) and mass flow (in which all the solids in the bin flow toward the outlet). Funnel flow can result in ratholing, doming or bridging of solids around the outlet, flooding, and difficulty in fully emptying a bin. Mass flow results in a smooth, even drawdown of solids from the bin. Jenike presents extensive data that can be used to determine the bin dimensions required to achieve mass flow with a particular bulk solid. ${ }^{3}$ These data are plotted in terms of measured flow characteristics of the individual solids, which are generally a function of particle size, moisture content, and time of standing. This theory assumes no aeration or vihratinn of the solids and therefore represents a worst-case approach.

\section{THEORY}

Jenike reasoned that any attempt to derive flow criteria for solids from liquid flow would be useless; he considered a bulk solid to be a plastic and viscoelastic continuum. Using such criteria, Jenike developed his theory of flow of bulk solids, which is used exclusively in this study. 3 Jenike's work developed the following concept. The pressure strength curve of a solid is referred to as its flow function, and the dashed line (Fig. 3) is called the flow factor of the channel. When these two lines intersect, the point of intersection usually determines the minimum size of the outlet required to assure unobstructed gravity flow. The flow function is a property of the solid. The flow factor is a property of the bin. The various pressures may be described by following the flow of a solid in a channel. The particles of the solid are initially deposited at the top of the mass 


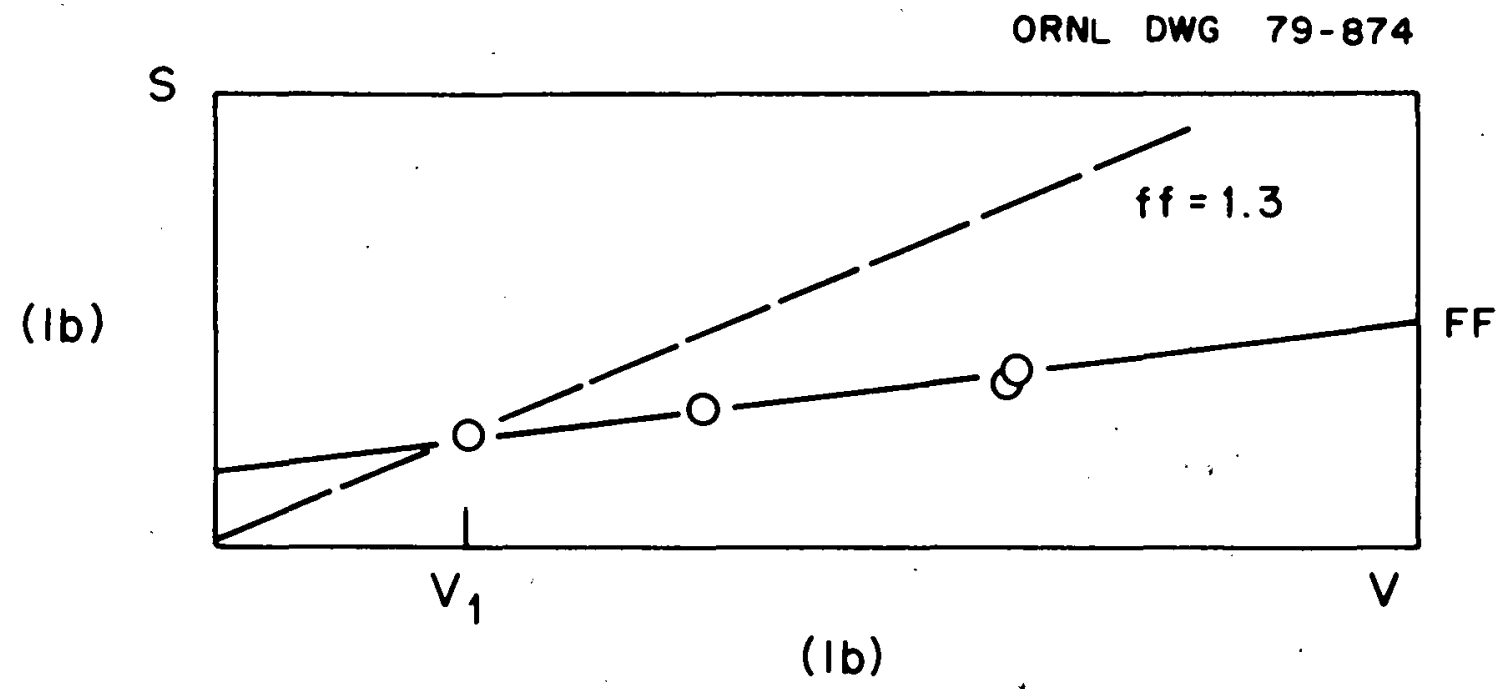

Fig. 3. Determination of major consolidating force.

without impact. As the individual particles flow down the channel, they are covered by more particles and the pressure increases steadily. An abrupt change of pressure occurs at the junction between the vertical walls of the bin and the conical hopper. The pressure then decreases linearly toward zero at the vertex. These varying pressures in the bin cause a change in density of the solid during flow and are called consolidating pressures. A Jenike and Johanson Flowfactor Tester can be used to measure the effect of these various pressures on the flow properties of the solids.

Although many obstructions to flow may develop in a bin, Jenike analyzed only two, doming and piping. It is assumed that if a bin were designed so that these two obstructions cannot occur, satisfactory flow will result. 


\section{MATERIALS TESTED}

\subsection{Attapulgite-150}

Attapulgite-150 is the trade name of a clay product from the palygorskite group of clay minerals and has the general formula $5 \mathrm{MgO} \cdot 8 \mathrm{SiO}_{2}$. $9 \mathrm{H}_{2}$. The attapulgite used in the shale fracturing operation has an unaerated bulk density of $35 \mathrm{lb} / \mathrm{ft}^{3}$ and an average particle size of approximately 100 mesh.

Moisture absorbed from the atmosphere has an effect on the flowability of solids. In the case of attapulgite, the effect of moisture is even more pronounced due to swelling. The attapulgite used in testing was not dried so that field conditions could be more closely approximated.

\subsection{F1y Ash}

The fly ash used is a bituminous ash received from the TVA steam plant at Kingston, Tennessee or from the Southeast Fly Ash Company, Kingsport, Tennessee. The particle size is less than 300 mesh and the unaerated bulk density is $54 \mathrm{lb} / \mathrm{ft}^{3}$.

of the properties that affect flow (i.e.. moisture, bulk density, and particle size), only particle size presents a potential problem with fly ash. Ash that is approximately 300 mesh and $15 \mu$ diam remains very dry in storage and has a moisture content of $\leq 0.15 \%$. Moisture acts as a particle binder, thus retarding flow.

\subsection{Pottery Clay}

Indian-red pottery clay is a dried and ground natural clay with an unaerated bulk density of $50 \mathrm{lb} / \mathrm{ft}^{3}$. Pottery clay does not swell on contact with water. 


\subsection{Cement}

Cement was not tested because there are no plans to store it in the new shale fracturing facility. Cement was used, however, as a component of the dry solids blend. Type-I Portland cement (ASTM C150) was used for this application.

\subsection{Dry Solids Blend}

The dry solids blend is a mixture consisting of 38.5 wt \% cement, 38.5 wt \% fly ash, 7.7 wt \% pottery clay, and 15.4 wt \% Attapulgite-150 drilling clay. Both field-blended and laboratory-blended samples were tested. A Patterson Kelly Company twin-shell dry blender was used for the laboratory samples.

\section{PROCEDURE}

Many factors must be considered in any attempt to determine the ideal flow characteristics to be designed into a storage bin. All solids do not gain the same strength under equal pressure. For instance, dry sand is cohesionless, but clay that contains little moisture is very cohesive and gains strength rapidly as a function of pressure. Other factors are time of applied pressure and temperature. Because the geometry of the bin is a major factor in this current work, the bin was considered to be a right circular cylinder with a vertical wall and a conical discharge hopper.

\subsection{Apparatus and Test Procedure}

A model FT-3STEH Jenike and Johanson Flowfactor Tester was used in all tests. Briefly, the instrument consists of a sample holder, a method of applying a consolidating force on the sample, and a stripchart recorder to measure the shear force. A vertical force is applied to the cover of the sample holder; the horizontal shearing force is applied by means of a gear-driven motor that advances a stem toward the shear cell. The shear force is applied to a brace attached to the cover. The force acts in the plane of contact between the ring and the base. The shear stress is recorded on a strip-chart recorder. 
The purpose of the tests is to measure the necessary flow functions, the bulk density, and the angle of friction between the solid and a material of the wall. Solids are consolidated at a given pressure and the force required to create a shear plane is measured. The procedure is repeated at several different consolidating pressures to determine a locus of points that can be displayed graphically. Prior to each shearing determination, a steady-state flow point is obtained. This point is always determined at the same consolidating pressure for a given set of data.

In the testing of a solid, vertical loads are assigned to provide a suitable distribution of results within the range of pressures expected in a storage bin. Bin pressures are proportional to the bulk density of a solid, and the load range varies appropriately. The weight ranges used were those recommended by Jenike and Johanson. ${ }^{4}$

\subsection{Wall Adhesion Tests}

The procedure for measuring the adhesion of a solid to a sample of bin wall material is to reduce the vertical load as soon as steady-state shearing force is achieved and continue until all weights are removed. The slope of the load vs the shearing force line determines the anglc of friction between a solid and a wall. The density of a solid at the outlet of a channel, which must be considered in the solids flow calculations, was obtained for each material tested.

\subsection{Plotting Test Results}

A typical set of test data are shown in Table 1. From these data, a set of flow function properties at this one particular preconsolidation load can be calculated.

'Table 1. Test un Attapulgite-150

\begin{tabular}{llll}
\hline & \multicolumn{3}{c}{ Test (1b) } \\
\cline { 2 - 4 } & \multicolumn{1}{c}{1} & 2 & 3 \\
\hline Preconsolidation load, $\mathrm{W}$ & 17.3 & 17.3 & 17.3 \\
Shearing force, $\mathrm{S}$ & 13.23 & 13.13 & 13.15 \\
Vertical load, $\overline{\mathrm{W}}$ & 15.3 & 10.3 & 5.3 \\
Shearing force, $\overline{\mathrm{S}}$ & 12.43 & 9.3 & 5.63 \\
\hline
\end{tabular}


The vertical loads are plotted against the shearing forces (Fig. 4) and a line is drawn through those three points that had a vertical load less than the preconsolidation load. The curve defined by the plotted points is referred to by: Jenike as the yield locus. The slope of this line, $\phi$, is called the angle of internal friction. A Mohr-force semicircle, passing through the origin and tangent to the yield locus curve, defines the unconsolidated yield strength, $F_{1}$, at the intercept of the horizontal axis. A second Mohr circle is drawn tangent to the yield locus and passes through point $W$ obtained at the preconsolidation load. The intercept of this circle and the horizontal axis (the intercept farthest from the origin) defines $v_{1}$, the major consolidation force. A line drawn from the origin to the tangent point between the yield locus and the larger Mohr circle is called the effective yield locus; the slope of this line $(\delta)$ is the effective angle of friction. The results from one test series can. thus be used to determine $\mathrm{F}_{1}, \mathrm{v}_{1}, \phi$, and $\delta$ for a single consolidation force.

ORNL DWG 79-873

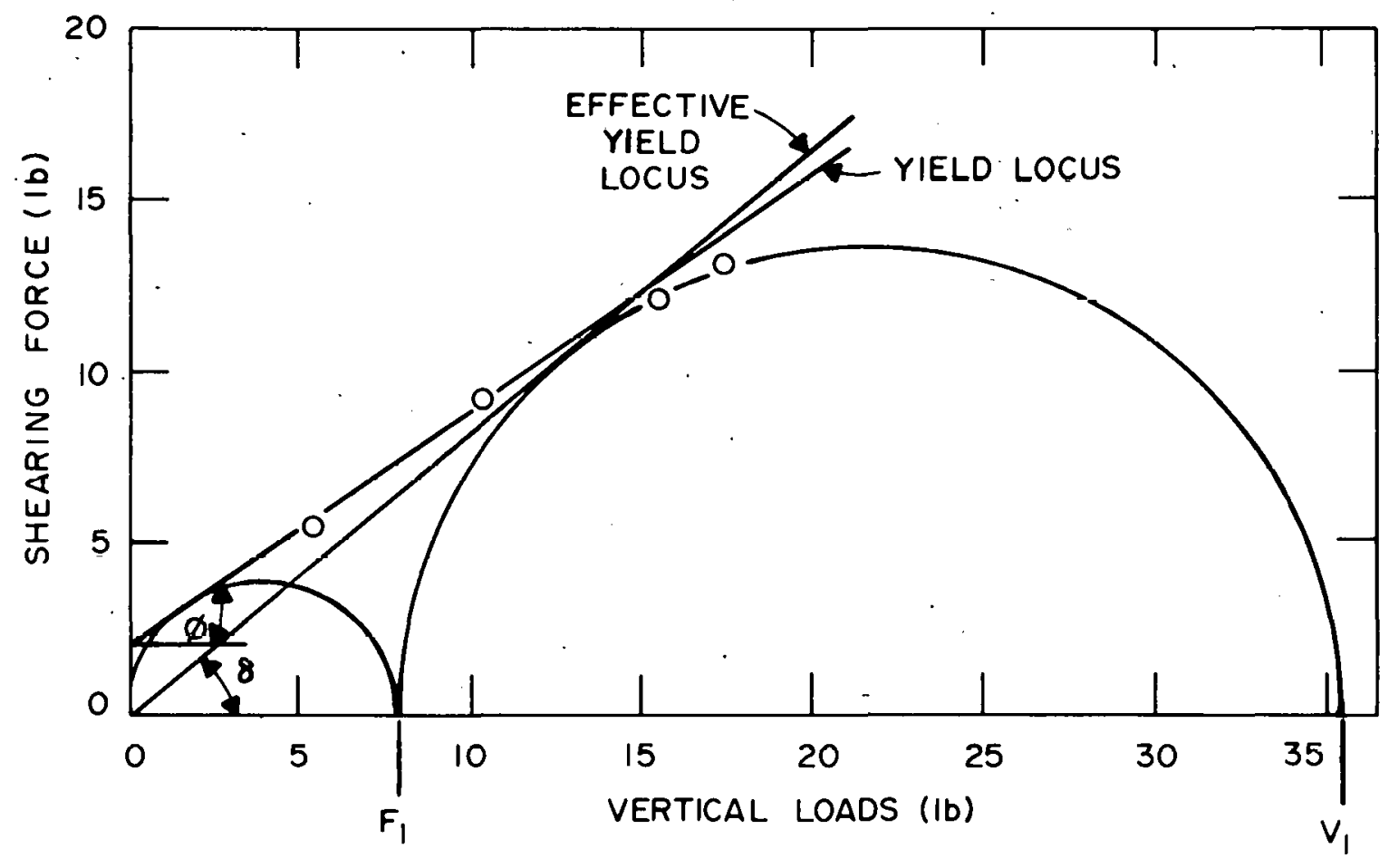

Fig. 4. Determination of consolidated yield strength and force. 
The above procedure is repeated several times at different consolidating loads, the values of $\mathrm{F}_{1}$ and $\mathrm{V}_{1}$ that are obtained are plotted, and the points are connected by a continuous line. This line defines the flow function of a given solid. On a force diagram this line is similar to line FF that was shown in Fig. 3 .

\section{DATA UTILIZATION}

The flow function, as described in Sect. 4, is used to calculate the minimum opening and the minimum cone angle required to permit uniform flow of bulk solids from a given bin. The flow function is a property of the material being tested and may vary with moisture, temperature, or particle size. Other necessary factors that must be determined experimentally are density and effective angle of friction. The final factor entering into the calculation of the minimum opening is called the flow factor. All flow factors used in this work have been determined by Jenike, which for a given bin are a function of the effective angle of friction $(\delta)$, the angle of friction between the solid and the wall material ( $\left.\phi^{\prime}\right)$, and the angle of the hopper cone (measured from the vertical). The effective angle of friction is determined from consolidation tests (Sect. 4); the angle of friction between solids and wall is determined from wall adhesion tests (Sect. 4.2). The relationship between these various functions was plotted by Jenike; a typical curve is shown in Fig. 5. The angle of the hopper cone is given by the intersection of the experimentally determined value of $\phi^{\prime}$ and the heavy diagonal line. This is the maximum limiting value of the hopper angle, and a safety margin of $3^{\circ}$ is then applied. This new point gives the maximum hopper angle for unaerated mass flow from a bin (by reading vertically downward) and the flow factor number (ff) for that particular bin (the contuur lines).

The flow factor number represents the slope of the ff line on the flow function curve, with one end of the line at the origin. The intercept between the ff line and the FF line (Fig. 3) is the major force in 


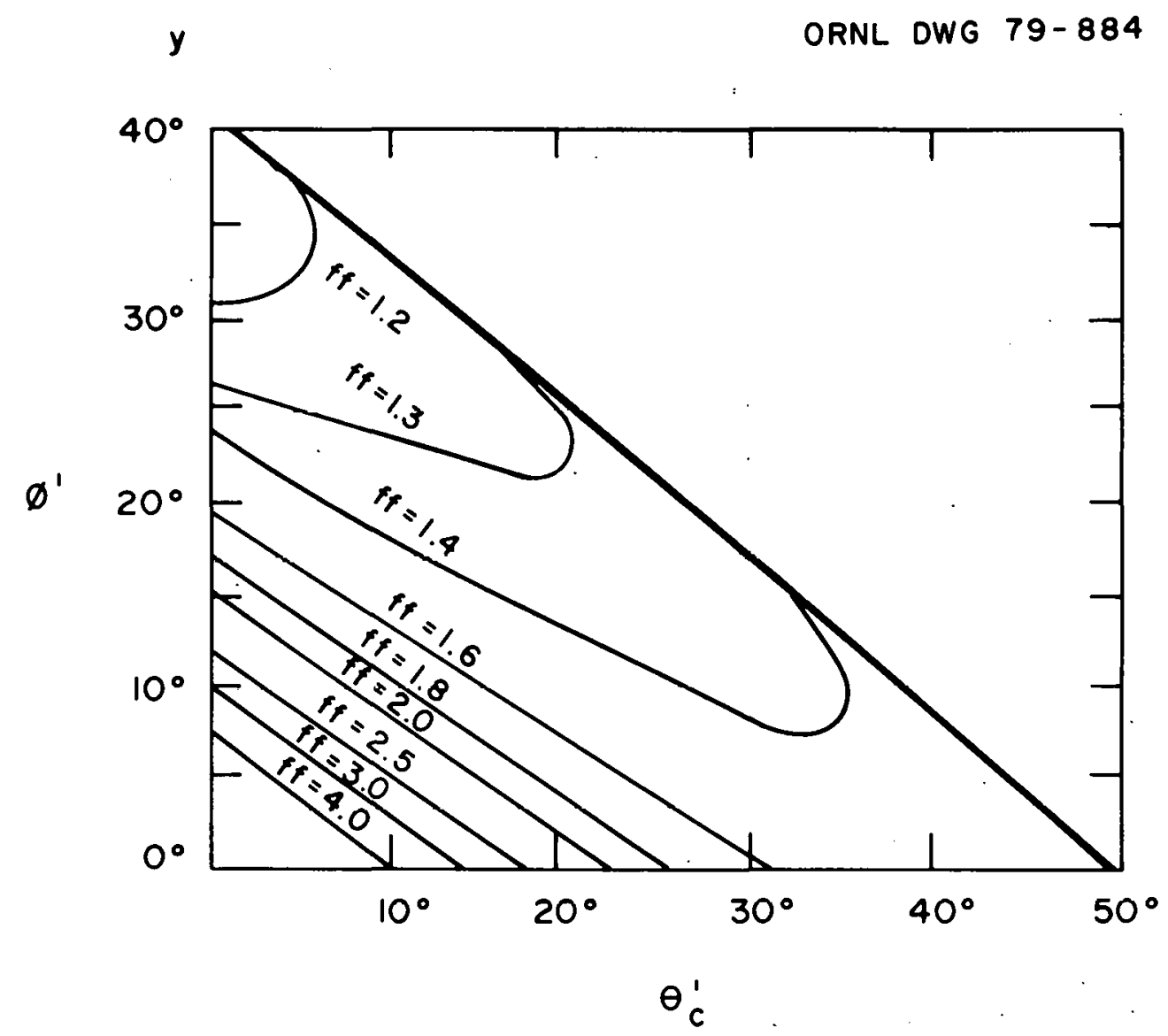

Fig. 5. Conical-channel ff contours, $\delta=50^{\circ}$. (Reproduced from "Storage and Flow of Solids," Utah Engineering Experiment Station Bulletin 123 , p. 88 ; courtesy of A. Jenike.)

a dome and is used to calculate the minimum diameter of the opening required for unobstructed flow. The equation used is:

$$
\mathrm{D}=\frac{\overline{\mathrm{V}}_{1} 13 \mathrm{H}\left(\phi^{\prime}\right)}{\text { density }}
$$

where

$$
\begin{aligned}
\mathrm{D}= & \text { opening diameter, ft; } \\
\overline{\mathrm{V}}_{1}= & \text { major force, } 1 \mathrm{~b} ; \\
\mathrm{H}\left(\phi^{\prime}\right)= & \text { geometric function of hopper slope angle, determined by } \\
& \text { Jenike for circular, square, and rectangular outlets; } \\
\text { density = } & \text { bulk solids density, } 1 \mathrm{~b} / \mathrm{ft}^{3} .
\end{aligned}
$$


6. RESULTS

The maximum hopper angles and minimum hopper-opening diameters for unaerated mass flow were determined for the various dry solids of interest, shown in Table 2 .

Table 2. Storage bin values for unpainted mild steel

\begin{tabular}{lcccc}
\hline $\begin{array}{l}\text { Material } \\
\text { stored }\end{array}$ & $\begin{array}{l}\text { Moisture } \\
\text { content } \\
\text { (wt \%) }\end{array}$ & $\begin{array}{l}\text { Hopper } \\
\text { angle } \\
\text { (deg) }\end{array}$ & $\begin{array}{l}\text { Internal } \\
\text { angle of } \\
\text { friction }\end{array}$ & $\begin{array}{c}\text { Bin opening } \\
\text { diam } \\
\text { (ft })\end{array}$ \\
\hline Attapulgite & 14.0 & 17.0 & 26.2 & 5.1 \\
Pottery clay & 1.9 & 12.0 & 29.6 & 6.9 \\
Fly ash & 0.12 & 23.5 & 19.0 & 1.6 \\
Standard dry mix & 3.3 & 21.0 & 24.2 & 4.0 \\
\hline
\end{tabular}

Bin-wall adhesion tests were determined for tour possible wall coatings. The major variations were observed with the standard dry mix. The adhesion angle ranged from $22.8^{\circ}$ to $27.0^{\circ}$ (Table 3 ).

Table 3. Adhesion angles for different wall coatings

\begin{tabular}{lcccc}
\hline & \multicolumn{4}{c}{$\begin{array}{c}\text { Adhesion } \\
\text { (deg) }\end{array}$} \\
\cline { 2 - 5 } $\begin{array}{l}\text { Coating } \\
\text { material }\end{array}$ & $\begin{array}{c}\text { Standard } \\
\text { mix }\end{array}$ & $\begin{array}{c}\text { F1y } \\
\text { ash }\end{array}$ & Attapulgite & $\begin{array}{c}\text { Pottery } \\
\text { clay }\end{array}$ \\
\hline Unpainted mild steel & 24.2 & 19.0 & 26.2 & 29.6 \\
$\begin{array}{l}\text { Exterior enamel } \\
\text { Auto paint lacquer }\end{array}$ & 27.0 & 20.8 & 24.4 & 29.7 \\
$\begin{array}{l}\text { Grey-Silka protective } \\
\text { coating }\end{array}$ & 22.8 & 20.8 & 24.4 & 28.7 \\
& 26.5 & 20.0 & 27.6 & 31.3 \\
\hline
\end{tabular}




\section{CONCLUSIONS}

The results indicate that a bottom hopper opening of about $4 \mathrm{ft}$ will be required on the new bulk storage bins if mass flow is to be achieved. These results also indicate that the existing bins are unsuitable for either the storage of dry $\operatorname{mix}$ or $\mathrm{mix}$ components; the existing hopper angle $\left(35^{\circ}\right)$ is much too large, and the existing hopper opening is much too small ( 8 in.). Because these bins have served moderately well for 14 years, it is obvious that aeration has a major effect. The tests described in this report do not consider this effect, and the results merely indicate an upper limit to the size of the opening that will be required. Thus, the opening in the new bulk storage tanks should be greater than $8 \mathrm{in}$. but less than the $48 \mathrm{in}$. indicated by this test.

Different coatings appear to make little difference in the flowability of the various solids.

Table 2 shows that pottery clay and attapulgite have flow characteristics considerably inferior to the standard dry $\mathrm{mix}$, and they might be difficult to remove from the existing storage bins if they are used for component storage. It is known, however, that attapulgite will flow from the existing bins; ${ }^{1}$ since the characteristics of pottery clay are only marginally worse than the characteristics of attapulgite, modifications of the bin bottoms to enlarge the openings does not appear to be justified.

\section{REFERENCES}

1. W. deLaguna et al., Engineering Development of Hydraulic Fracturing as a Method for Permanent Disposal of Radioactive Wastes, ORNL-4259 (1968).

2. H. O. Weeren, Nucl. Eng. Des. 44, 291 (1977).

3. A. W. Jenike, "Storage and Flow of Solids," Bulletin 123 of the Utah Engineering Experiment Stat1on, 7th ed. (1970).

4. "Flowfactor Tester and Consolidating Bench Operating Instructions," Jentke and Johanson, Inc., North Bellerica, Mass., 1978. 


\section{THIS PAGE \\ WAS INTENTIONALLY \\ LEFT BLANK}


INTERNAL DISTRIBUTION

1. H. S. Arora

2. F. N. Case

3. N. H. Cutshall

4. C. S. Fore

5. R. W. Glass

6. H. W. Godbee

7. K. W. Haff

8. T. F. Lomenick

9. A. L. Lotts

10. R. E. Lampston

11-16. E. W. McDaniel

17. C. P. McGinnis

18. J. G. Moore

19. E. Newman
20. H. A. Pfuderer

21. R. A. Robinson

22. G. C. Rogers

23-28. H. O. Weeren

29. G. A. West

30. R. G. Wymer

31. G. T. Yeh

32. V. A. Jacobs

33. Document Reference Section

34-39. Laboratory Records

40. Laboratory Records - RC

41. ORNL Patent Section

42-44. Central Research Library

\section{EXTERNAL DISTRIBUTION}

45. Office of Assistant Manager, Energy Research and Development, DOE-ORO, P. O. BOX E, Oak Ridge, TN 37830

46. D1rector, Nuclear Research and Development Division, DOE-ORO, P. O. Box E, Oak Ridge, TN 37830

47. W. F. Bennett, Rocky Flats Area Office, P. 0. Box 928, Golden, CO 80401

48. G. H. Daly, Chief, Technology Branch, Division of Waste Products, Office of Nuclear Waste Management, Mail Stop B-107, U. S.

Department of Energy, Washington, DC 20545

49. J. E. Dieckhoner, Chief, Operations Branch, Division of Waste Products, Office of Nuclear Waste Management, U..S. Department of Energy, Washington, DC 20545

50. E. W. Goldberg, Chief of Waste Management, Savannah River Operations Office, P. O. Box A, Aiken, SC 29801.

51-52. D. E. Large, DOE-ORO, P. O. Box E, Oak Ridge, TN 37830

53. G. Levin, EG\&G Idaho, Inc., Box 1625, Idaho Falls, 83401

54. R. Y. Lowrey, Chlef, Waste Management Branch, Albuquerque Operations office, P. O. Box 5400, Albuquerque, NM 87115

55. G. Oertel, Director, Division of Waste Products, Office of Nuclear Waste Management, U. S. Department of Energy, Washington, DC 20545 
56. J. W. Peel, Radioactive Waste Management, U. S. Department of Energy, Idaho Operations Office, 550 Second Street, Idaho Falls ID 83401

57. J. B. Whitsett, Chief of Radioactive Waste Management, U. S. Department of Energy, Idaho Operations Office, 550 Second Street, Idaho Falls, ID 83401

58-390. Given distribution as shown in TID-4500 under UC-70, Nuclear Waste Management 